\title{
A COMPARATIVE STUDY OF EFFECTS OF AVERSECTIN C, ABAMECTIN AND IVERMECTIN ON APOPTOSIS OF RAT THYMOCYTES INDUCED BY RADIATION AND DEXAMETHASONE
}

\author{
YU. N. KORYSTOV ${ }^{1,2}$, V. A. MOSIN ${ }^{1}$, V. V. SHAPOSHNIKOVA ${ }^{2}$, M. KH. LEVITMAN ${ }^{2}$, \\ A. A. KUDRYAVTSEV ${ }^{2}$, E. B. KRUGLYAK ${ }^{1}$, T. S. STERLINA ${ }^{1}$, A. V.VIKTOROV ${ }^{1 *}$, \\ V. A. DRINYAEV 1 . \\ ${ }^{1}$ Pharmbiomed Company, Moscow, Russia \\ ${ }^{2}$ Institute of Theoretical and Experimental Biophysics, Russian Academy of Sciences, \\ Moscow Region, Pushkhino, Russia
}

Received November 11, 1998

Accepted January 14, 1999

\section{Abstract}

Korystov Yu. N., V. A. Mosin, V. V. Shaposhnikova, M. Kh. Levitman, A. A. Kudryavtsev, E. B. Kruglyak, T. S. Sterlina, A. V.Viktorov, V. A. Drinyaev: A Comparative Study of Effects of Aversectin C, Abamectin and Ivermectin on Apoptosis of Rat Thymocytes Induced by Radiation and Dexamethasone. Acta Vet. Brno 1999, 68: 23-29.

The effects of avermectins on radiation- and dexamethasone-induced apoptosis of rat thymocytes have been studied. In particular, the properties of abamectin (avermectin $\mathrm{B}_{1}$ ), ivermectin (22,23-dihydroavermectin $\left.\mathrm{B}_{1}, \mathrm{H}_{2} \mathrm{~B}_{1}\right)$ and aversectin $\mathrm{C}$ were examined. Aversectin $\mathrm{C}$ is a mixture of eight naturally occurring avermectins of the following composition: $\mathrm{B}_{1}(42 \%), \mathrm{B}_{2}$ $(22 \%), \mathrm{A}_{1}(13 \%)$ and $\mathrm{A}_{2}(23 \%)$. This mixture is currently widely used as active ingredient in veterinary antiparasitic formulations produced by Pharmbiomed Co. Apoptosis was estimated by membrane damage, nuclear pycnosis (or chromatin condensation), DNA fragmentation and percentage of cells with subdiploid DNA. It was shown that aversectin C inhibits thymocyte apoptosis induced by both agents. The $\mathrm{IC}_{50}$ dose was in the range of $0.1-0.3 \mu \mathrm{g} / \mathrm{ml}$ for aversectin $\mathrm{C}$, whereas abamectin and ivermectin produced no effect up to $1 \mu \mathrm{g} / \mathrm{ml}$. It is suggested that avermectins of the A series are responsible for the high anti-apoptotic activity exhibited by aversectin C. Thus, aversectin $\mathrm{C}$ is not only an effective antiparasitic drug but is also capable of exhibiting some other useful activities, e.g. a cytoprotective effect exerted on the mammalian immune cells.

Avermectins, antiparasitic drugs, apoptosis, thymocytes, dexamethasone, gamma rays

The avermectins are a family of closely related 16-membered macrocyclic lactones produced by the fungus Streptomyces avermitilis. Nearly all the avermectins exhibit a broad spectrum of activity against nematode and arthropode parasites, with the $\mathrm{B}_{1 \mathrm{a}}$ compound being the most potent (Campbell 1989). Accordingly, it was used as active ingredient in commercial antiparasitic formulations. Until recently, there were basically two types of such avermectin-based active ingredients, i.e. ivermectin (consisting mainly of avermectin $\mathrm{H}_{2} \mathrm{~B}_{1 \mathrm{a}}$ ) and abamectin (predominantly containing avermectin $\mathrm{B}_{1 \mathrm{a}}$ ). However, several years ago the Pharmbiomed Co. started manufacturing the veterinary and plant protection formulations based on a new active ingredient - aversectin $C$ which is an intrinsic mixture of eight naturally occurring avermectins. Preliminary experiments demonstrated that aversectin $\mathrm{C}$ (presumably due to the presence of avermectins of both the A- and B-series) possesses some new useful features compared to ivermectin and abamectin, e.g. with the same high efficacy, the spectrum of activity is broader, level of residues is lower and, hence, the shorter withdrawal periods could be recommended (Simetsky et al. 1994; Berezkina et al. 1996). Furthermore, degradation of aversectin C in soil and water was found to be more effective compared to abamectin and ivermectin (Mosin et al. 1998) and, hence, ecologically aversectin $\mathrm{C}$ is safer. 
The study of avermectins as antiparasitic drugs has been focused so far exclusively on the effects of the $\mathrm{B}_{1}$ component and its derivative $\mathrm{H}_{2} \mathrm{~B}_{1}$ (ivermectin). It was shown that abamectin and ivermectin are lethal for invertebrates and relatively non-toxic for mammals (Campbell 1989; Cully et al. 1996; Vassilatis et al. 1997; Huang and Casida 1997). Although the mechanisms of action of avermectins in animals and humans are not completely studied yet, ivermectin is now considered as a drug of choice to treat onchocercosis in humans (Campbell 1989) and it has been successfully used against some human ectoparasites (Y oussef et al. 1995).

There are a few reports on changes in the immune system in humans and animals associated with ivermectin treatment of some parasitic diseases. Thus, ivermectin increased the antibody level and antibody-dependent cytotoxicity in animals ( Ra o et al. 1987). Also, an increase in the $\mathrm{T}$ and $\mathrm{B}$ cell proliferation rate in vitro in response to different antigens was observed in cells isolated from man treated with ivermectin (Lammie et al. 1992). Quite recently, it was shown that both aversectin $\mathrm{C}$ and ivermectin can somewhat reduce in mammals the level of B-lymphocytes and T-helpers, with aversectin $\mathrm{C}$ being less immunosuppressive (Sivkov et al. 1998).

Here we present a comparative study of the effects of aversectin C, abamectin and ivermectin on the radiation- and dexamethasone-induced apoptosis in rat thymocytes. It was found that aversectin $\mathrm{C}$ significantly inhibits apoptosis, while abamectin and ivermectin are ineffective.

\footnotetext{
Materials and Methods

Reagents

Ivermectin and abamectin were supplied by Merck Co. (Germany). HPLC grade solvents were also purchased from Merck. Cell culture media and all other reagents were products of Sigma Co. (St. Louis, MO, USA).

Thymocyte isolation and treatment

Thymocytes were isolated from male Wistar rats (140-160 g) by a standard procedure (Eidus et al. 1990). The cells were irradiated with ${ }^{60} \mathrm{Co}$ gamma rays at a dose rate of $2.1 \mathrm{~Gy} / \mathrm{min}$ at room temperature. Dexamethasone $\left(2 \times 10^{-7} \mathrm{M}\right)$ was administered to the cells just before incubation at $37^{\circ} \mathrm{C}$. The incubation was carried out in 96 -well flat-bottomed plates using $200 \mu \mathrm{l}$ cell suspension $\left(3 \times 10^{6}\right.$ cells $)$ per well. Avermectins were added to the cell culture as ethanolic solutions (1-3 $\mu \mathrm{g} / \mathrm{ml}$ stock concentrations) immediately after the irradiation procedure or administration of dexamethasone. Ethanol concentration in cultural media did not exceed $0.1 \%$ which produced no effects on any parameters studied.
}

Determination of cell death

Cell death was evaluated by the decrease in cell number (cell lysis) and by staining of cells with a $0.04 \%$ solution of the trypan blue dye after $24 \mathrm{hrs}$ incubation ( $\mathrm{Rao}$ et al. 1987) and expressed as the decrease in cell survival (S): $\mathrm{S}=\mathrm{N}_{\mathrm{f}} / \mathrm{N}_{\mathrm{i}} \times 100 \%$, where $\mathrm{N}_{\mathrm{f}}$ is the final concentration of unstained cells and $\mathrm{N}_{\mathrm{i}}$ is the initial concentration of unstained cells.

Determination of nuclear damage

Nuclear damage was evaluated by the chromatin condensation (nuclear pycnosis) and fragmentation of condensed chromatin (nuclear fragmentation) as described in detail elsewhere (Eidus et al. 1994; SchulzeOsthoff et al. 1994). Briefly the damaged nuclei were identified with acetic acid-ethanol (1:3) fixation and Giemsa staining after $6 \mathrm{~h}$ incubation.

Determination of cell DNA content

The percentage of cells with subdiploid set of DNA (sub- $\mathrm{G}_{1}$ cells) was determined on a flow cytometer (laboratory set-up). Cells were fixed with a cold $70 \%$ ethanol after a $6 \mathrm{hr}$ incubation, transferred into phosphate buffer ( $\mathrm{pH} 7.2)$, and stained with a Hoechst 33258 dye for $5 \mathrm{~min}(2 \mathrm{mg} / \mathrm{ml})$. In each series, $(20-50) \times 10^{3}$ cells were assayed. The relative amount of cells with DNA content corresponding to different stages of the cell cycle was determined from experimental histograms by using PC. Peak assignment in histograms was made according to Dean and Jeft (1974).

Determination of DNA fragmentation

DNA fragmentation was determined in approximately $1.5 \times 10^{7}$ cells $6 \mathrm{hr}$ after incubation according to procedure (Perotti et al. 1990).

HPLC method

Reversed-phase HPLC analyses of composition of aversectin $\mathrm{C}$ and purity of abamectin and ivermectin were performed with a Hewlett Packard (1050 series) liquid chromatograph (Germany) equipped with a UV variable 
wavelength detector (set to $243 \mathrm{~nm}$ ) operating on-line with PC and using a «Multichrom for Windows» software (Ampersand Co., Russia) to acquire and process chromatographic data. The following chromatographic conditions were used: isocratic elution with methanol/acetonitrile/water $(65: 20: 15, \mathrm{v} / \mathrm{v} / \mathrm{v} /)$ mixture; analytical Ultrasphere ODS $(4.6 \times 250 \mathrm{~mm})$ column with ODS precolumn; $1 \mathrm{ml} / \mathrm{min}$ flow rate. Individual avermectin components were identified by their retention times in comparison with authentic commercial standards and published data (Novak et al. 1993).

MALDI mass-spectrometry

Mass-spectra of aversectin $\mathrm{C}$ were obtained with a MALDI TOF VISION 2000 spectrometer (ThermoBioanalysis, U.K.) operating on-line with PC. The UV laser was set to $337 \mathrm{~nm}$; DHB matrix was used. All avermectins were registered as sodium monovalent molecular cations. Typically 5-20 pmoles of avermectins were used for each MALDI-MS analysis. Under these conditions, practically no fragmentation of the avermectin molecule was observed.

\section{Aversectin $\mathrm{C}$ characterization}

Aversectin C represents a dried semi-purified ethanolic extract of Streptomyces avermitilis mycelia in which avermectin content (active ingredient) is about 86-90\% and impurities consist of: avermectin-related compounds $(5-9 \%)$; neutral lipids $(4 \%)$; proteins $(<1 \%)$; salts $(<1 \%)$. HPLC chromatograms of aversectin C demonstrated the following avermectin profile: $\mathrm{A}_{1 \mathrm{a}}-9 \% ; \mathrm{A}_{1 \mathrm{~b}}-4 \% ; \mathrm{B}_{1 \mathrm{a}}-36 \% ; \mathrm{B}_{1 \mathrm{~b}}-6 \% ; \mathrm{A}_{2 \mathrm{a}}-19 \% ; \mathrm{A}_{2 \mathrm{~b}}-4 \% ; \mathrm{B}_{2 \mathrm{a}}-21 \% ; \mathrm{B}_{2 \mathrm{~b}}-1 \%$. MALDI-MS spectra of aversectin $\mathrm{C}$ (not shown) confirmed the presence of major avermectin constituents registered as sodium monovalent molecular cations with masses (m/z): 909 (for $\mathrm{A}_{1 \mathrm{a}}$ ), 895 (for $\mathrm{B}_{1 \mathrm{a}}+\mathrm{A}_{1 \mathrm{~b}}$ ), 927 (for $\mathrm{A}_{2 \mathrm{a}}$ ) and 913 (for $\mathrm{B}_{2 \mathrm{a}}+\mathrm{A}_{2 \mathrm{~b}}$ ). Furthermore, every avermectin component in aversectin $\mathrm{C}$ was isolated and characterized separately using physico-chemical methods.

\section{Results}

Effect of aversectin $\mathrm{C}$ on apoptosis in thymocytes

Curves in Fig. 1 show the effect of aversectin $C$ on cell survival (Fig. 1A), DNA fragmentation (Fig. 1B) and nuclear damage (Fig. 1C) in control, irradiated and

A. Cell survival

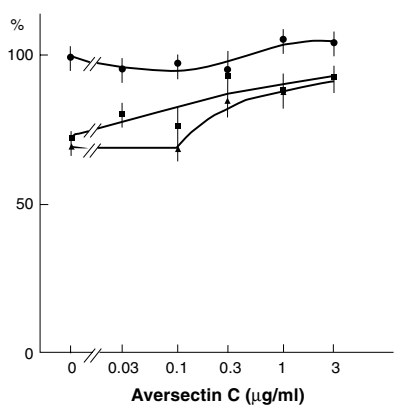

B. DNA fragmentation

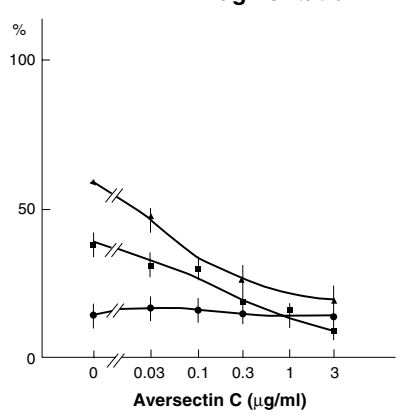

C. Nuclear damage

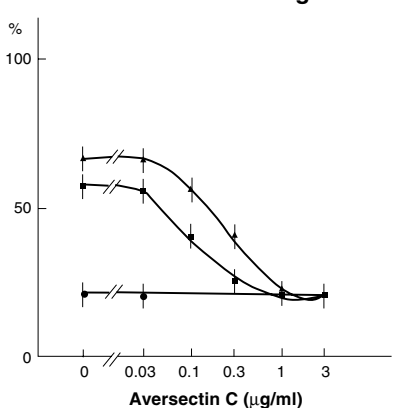

Fig. 1. Effect of aversectin C on: cell survival (A), DNA fragmentation (B) and nuclear damage (C) of control ( ), irradiated with 6 Gy dose $(\mathbf{A})$ and $0.2 \mathrm{mM}$ dexamethasone $(\mathbf{\square})$ treated thymocytes $(\mathrm{n}=5)$

dexamethasone treated thymocytes as a function of the drug concentration. At none of the concentrations studied did aversectin $\mathrm{C}$ influence these parameters in control cells. However, as concentration of aversectin $\mathrm{C}$ was increased, the manifestation of apoptosis in treated cells was progressively diminished: a significant increase in survival rate, decrease in DNA fragmentation and nuclear damage were observed both in irradiated and in dexamethasone-treated thymocytes. For irradiated cells, the addition of aversectin $\mathrm{C}$ at concentration of about $0.1 \mu \mathrm{g} / \mathrm{ml}$ resulted in a decrease in DNA fragmentation (Fig. 1B) to approximately a half between control and radiation-induced level (the $\mathrm{IC}_{50}$ dose). In analogous way, aversectin $\mathrm{C}$ caused inhibition of thymocyte apoptosis triggered by 
A

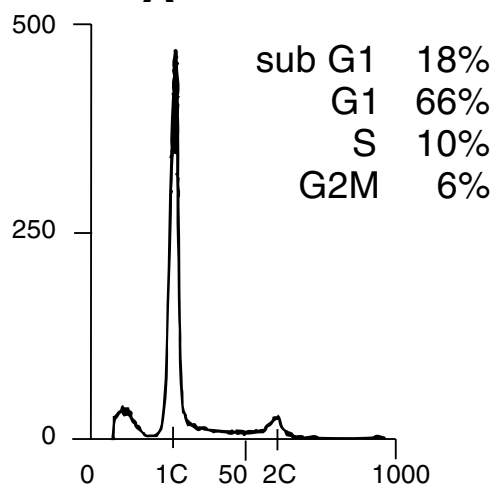

C

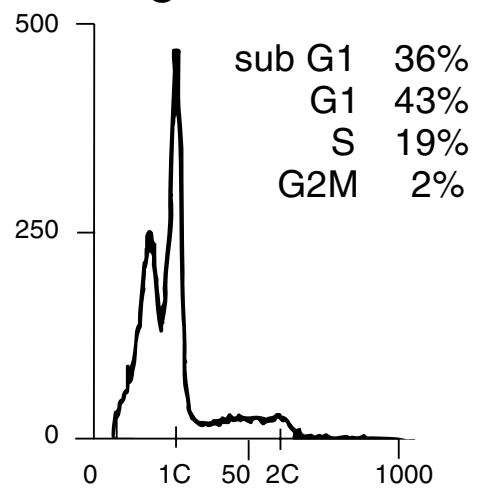

E

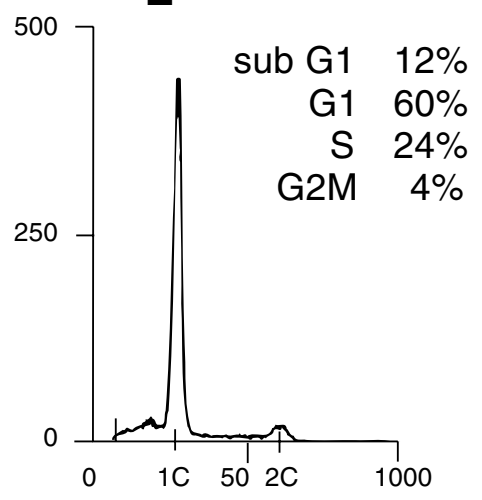

B

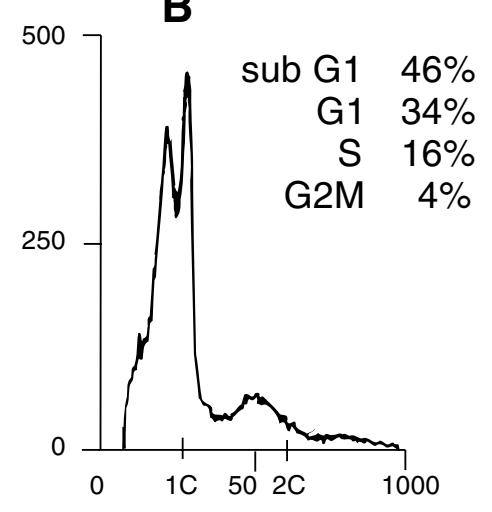

D

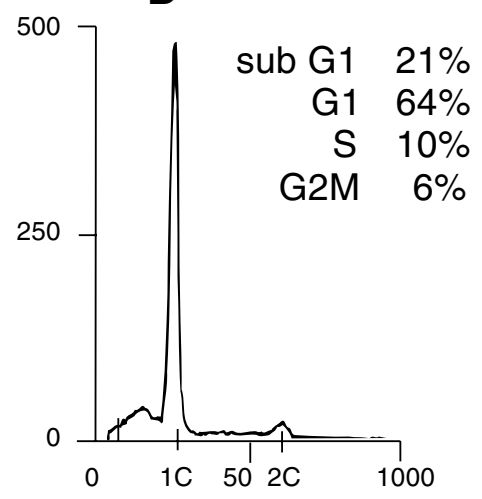

Fig. 2. Distribution of thymocytes with respect to DNA content in control (A), after irradiation with a dose of $6 \mathrm{~Gy}(\mathrm{~B}), 0.2 \mathrm{mM}$ dexamethasone treatment (C) and after administration of $1 \mu \mathrm{g} / \mathrm{ml}$ aversectin $\mathrm{C}$ to irradiated (D) and dexamethasone treated

(E) cells (characteristic curves of one experiment are presented). Symbols "1C and 2 C" denote DNA content in G1 and G2, $\mathrm{M}$ cell cycle phases, respectively 
dexamethasone: the $\mathrm{IC}_{50}$ dose was found to be close to $0.3 \mu \mathrm{g} / \mathrm{ml}$ (Fig. 1A-B). Similar results were obtained for the third parameter of apoptosis studied here, i.e. nuclear damage, when it was shown that aversectin $\mathrm{C}$ strongly reduced both dexamethasone- and radiation-induced damage of nuclei in treated cells but produced no change in control thymocytes (Fig. 1C). The $\mathrm{IC}_{50}$ value calculated for this criterion was about $0.1-0.2 \mu \mathrm{g} / \mathrm{ml}$ and at $1 \mu \mathrm{g} / \mathrm{ml}$ concentration of the drug percentage of nuclei damage was decreased to control level.

Effect of aversectin $\mathrm{C}$ on distribution of cells with respect to DNA content

The flow cytometry data showing the relative amount of cells with different sets of DNA corresponding to different stages of the cell cycle (sub- $\mathrm{G}_{1}, \mathrm{G}_{1}, \mathrm{~S}$ and $\left.\mathrm{G}_{2}, \mathrm{M}\right)$ are presented in Fig. 2. After irradiation and dexamethasone treatment, the portion of apoptotic cells with subdiploid DNA (sub- $\mathrm{G}_{1}$ ) was significantly augmented (Fig 2B and 2C). Administration of aversectin $\mathrm{C}$ reduced the percentage of apoptotic cells for both treatments to control levels (Fig. 2D and 2E). The dose dependence of this effect demonstrated that a decrease in percentage of apoptotic cells was accompanied by an increase in the portion of $\mathrm{G}_{1}$ cells as concentration of aversectin $\mathrm{C}$ was increased (data not shown).

Effect of aversectin $\mathrm{C}$, abamectin and ivermectin on DNA fragmentation

Fig. 3 shows the effect of different active ingredients on DNA fragmentation in control, irradiated and dexamethasone-treated thymocytes. Upon administration of any substance no alteration in the

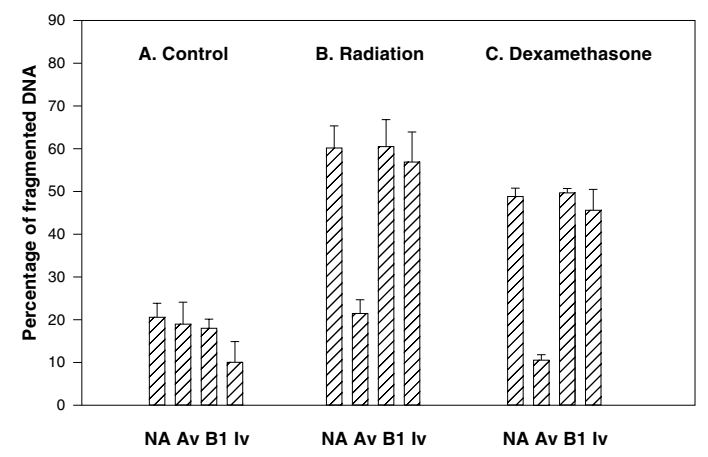

Fig. 3. Effect of aversectin $\mathrm{C}$ (Av), abamectin (B1) and ivermectin (Iv) on DNA fragmentation in control (A), 6 Gy irradiated (B) and $0.2 \mathrm{mM}$ dexamethasone treated (C) thymocytes $(n=3)$. Samples to which no avermectins were added are denoted as NA. All avermectins were added at $1 \mu \mathrm{g} / \mathrm{ml}$.

DNA fragmentation pattern in control thymocytes was revealed. However, irradiation and dexamethasone treatments induced a noticeable DNA fragmentation which could be abolished by addition of aversectin $\mathrm{C}$ only; abamectin and ivermectin turned out to be ineffective.

\section{Discussion}

The present work describes for the first time effects of aversectin $\mathrm{C}$, abamectin and ivermectin on mammalian immunocompetent cells - the rat thymocytes. In particular, the ability of these compounds to affect apoptosis induced by radiation and dexamethasone treatment was examined. Judging by parameters characteristic for apoptosis, i.e. cell survival, DNA fragmentation, nuclear damage and DNA cell distribution pattern, we can conclude that administration of avermectins to control cells produced no detectable changes. However, application of aversectin $\mathrm{C}$ to either irradiated or dexamethasone treated 
thymocytes significantly blocked the development of apoptosis, whereas abamectin and ivermectin were much less effective. It seems only reasonable to suggest that avermectins of the A group, present in aversectin $\mathrm{C}$ in tangible amounts (about $36 \%$ ), should be mainly responsible for the observed activity.

The mechanisms of apoptosis are very complex and diverse with a great number of substances capable of triggering the process and many effector molecules are required for it to develop. Ununexpectedly, apoptosis is still poorly understood. However, the structural and biochemical changes occurring in apoptotic cells are rather consistent and common for many cells and agents and, hence, can be used as reliable criteria. It is well documented that mechanisms of apoptosis triggered in thymocytes by ionizing radiation and dexamethasone are different. In particular, the radiation- but not dexamethasone-induced apoptosis depends on p53 gene (Williams and Smith 1993). Furthermore, the membrane damage, chromatin condensation and DNA fragmentation are known to follow the different metabolic pathways (Eidus et al. 1994; Schulze-Osthoff et al. 1994; Sun et al. 1994). Aversectin C suppresses apoptosis induced by both agents according to all criteria used. This implies that it is capable of blocking apoptosis at a very early stage which is crucial to all subsequent damages of different cell structures characteristic for apoptosis. Unfortunately, basing on our present results no suggestions on how aversectin $\mathrm{C}$ exerts its anti-apoptotic effects in thymocytes and what particular sites are targeted in the cell can be made.

Finally, the obtained results allow us to recommend to use the veterinary preparations based on aversectin $\mathrm{C}$, instead of those containing abamectin or ivermectin, in cases when animals experience some immune problems.

\section{Srovnání vlivu Aversectinu A, Abamectinu a Ivermectinu na apoptózu thymocytů potkana po indukci radiací a dexamethasonem}

Vliv avermectinů na apoptózu indukovanou radiací a dexamethasonem byl sledován $\mathrm{v}$ thymocytech potkana. Sledovány byly zejména vlastnosti abamectinu (avermectin $\mathrm{B}_{1}$ ), ivermectinu (22,23-dihydroavermectin $\left.\mathrm{B}_{1}, \mathrm{H}_{2} \mathrm{~B}_{1}\right)$ a aversectinu $\mathrm{C}$. Aversectin $\mathrm{C}$ je směsí osmi přirozeně se vyskytujících avermectinů následujícího složení: $\mathrm{B}_{1}(42 \%), \mathrm{B}_{2}(22 \%)$, $\mathrm{A}_{1}(13 \%)$ a $\mathrm{A}_{2}(23 \%)$. Nyní je často užíván jako aktivní substance veterinárních antiparazitik firmy Pharmbiomed Co. Ukazatelem apoptózy bylo poškození buněčné membrány, pyknóza jádra (anebo kondenzace chromatinu), fragmentace DNK a procento buněk se subdiploidní DNK. Ukázalo se, že aversectin C inhibuje apoptózu thymocytů indukovanou radiací nebo dexamethasonem. Dávka $\mathrm{IC}_{50}$ se pohybovala od $0,1-0,3 \mu \mathrm{g} / \mathrm{ml} \mathrm{u}$ avermectinu $\mathrm{C}$, abamectin a ivermectin nevyvolal efekt ani při dávce do $1 \mu \mathrm{g} / \mathrm{ml}$. Výsledky naznačují, že avermectiny serie A mají vysokou antiapoptotickou aktivitu, kterou vykazuje aversectin C. Je tedy nejen účinným antiparazitikem, ale je užitečný i jinak, např. má u savčích buněk cytoprotektivní efekt.

\section{References}

BEREZKINA, S. V., DRINYAEV, V. A., GOLOVKINA, L. P., VICTOROV, A. V., GRIGORIEVA, S. P., GORSHKOVA, N. G., YURKIV V. A. 1996: Efficacy of pharmacin (aversekt-2) at hypodermatosis in cattle. Veterinaria (Russian), No. 6: $30-35$

CAMPBELL, W. C. 1989: Ivermectin and Abamectin, Springer-Verlag, New York.

CULLY, D. F., PARESS, P. S., LIU, K. K., SCHAEFFER, J. M., ARENA, J. P. 1996: Identification of a Drosophila melanogaster glutamate-gated chloride channel sensitive to the antiparasitic agent avermectin J. Biol. Chem. 271: 20187-20191

DEAN, P. N., JEFT, J. H. 1974; Mathematical analysis of DNA distribution derived from flow microfluorometry. J. Cell Biol. 60: 523-527

EIDUS, L. KH., KORYSTOV, YU. N., DOBROVINSKAYA, O. R., SHAPOSHNIKOVA, V. V. 1990: On the cause-sequence relationship between different criteria of ionizing radiation induced damage in thymocytes. Radiat. Res. 123: 17-21 
EIDUS, L. KH., SHAPOSHNIKOVA, V. V., DOBROVINSKAYA, O. R., KORYSTOV, YU. N. 1994: Mechanism of radiation-induced interphase death of lymphoid cells: a new hypothesis. Radiat. Biol. Radioecol. (Russian) 34: 79-89

HUANG, J., CASIDA, J. E. 1997. Avermectin B1a binds to high and low affinity sites with dual effects on the GABA-gated chloride channel of cultured cerebella granule neurons. J. Pharmacol. Exper. Ther. 281: 261-266

LAMMIE, P. J., HIGHTOWER, A. W., RICHARDS, F. O., BRYAN, R. T., SPENCER, H. C., MCNEELEY, D. F., MCNEELEY, M. B., EBERHARD, M. L. 1992: Alterations in filarial antigen-specific immunologic reactivity following treatment with ivermectin and diethylearbamazine. Am. J. Trop. Med. Hyg. 46: 292-295

MOSIN, V. A., SAMORUKOV, D. E., KRUGLYAK, E. B., DRINYAEV, V .A., YURKIV, V .A. 1998: Study of degradation of aversectin C in water. Ekologia (Russ.) No 2: 147-149

NOVÁK, J., BERAN, M., NÉMEČEK, J., PŘIKRYLOVÁ, V., HÁJEK, P. 1993; Production of avermectin A2a and monoglycosides A2a and B2a by a strain of Streptomyces avermitilis. Folia Microbiol. 38: 367-370

PEROTTI, M., TODDEY, F., MIRABELli, F., VAIRETTI, M., BELlOMO, G., MCCONKEY, D., ORRENIUS, S. 1990: Calcium-dependent DNA fragmentation in human synovial cells exposed to cold shock. FEBS Lett. 259: 331-334

RAO, U. R., CHANDRASHEKAR, R., SUBRAHMANYAN, D. 1987: Effect of ivermectin on serum dependent cellular interactions to Dipetaloma viteae microfilariae. Trop. Med. Parasitol. 38: 123-127

SCHULZE-OSTHOFF, K., WALCZAK, H., DROGE, W., DROGE, W., KRAMER, P. H. 1994: Cell nucleus and DNA fragmentation are not required for apoptosis. J. Cell. Biol. 127: 15-20

SIMETSKY, M. A., UDAVLIEV, D. I., FILIPPOV, V. V., MOSIN, V. A., KRUGLYAK, E. B., DRINYAEV, V. A., YURKIV, V. A. 1994; Comparative study of efficacy of ivomec and aversekt. Veterinaria (Russian) No 1: 40-42

SIVKOV, G. S., YAKOVLEVA, V. V., CHASHKOVA, I. A., GOLOVKINA, L. P., DRINYAEV, V. A., YURKIV, V.A. 1998; Influence of ivomec and pharmacin (aversekt-2) on the immune response in animals. Veterinaria (Russian) No 5: 29-31

VASSILATIS, D. K., ELLISTON, K. O., PARESS, P. S., HAMELIN, M., ARENA, J. P., SCHAEFFER, J. M., VANDER PLOEG, L. H., CULLY, D. F. 1997: Evolutionary relationship of the ligand-gated ion channels and the avermectin-sensitive, glutamate-gated chloride channels. J. Mol. Evol. 44: 501-508

WILLIAMS, G. T., SMITH, C. A. 1993: Molecular regulation of apoptosis: genetic controls on cell death. Cell 74: $777-779$

YOUSSEF, M. Y. M., SADAKA, H. A. H., EISSA, M. M., EL-ARINY, A. F. 1995: Topical application of ivermectin for human ectoparasites. Am. J. Trop. Med. Hyg. 53: 652-653

Abbreviations used in the text: DHB, 2,5-dihydroxybenzoic acid; EDTA, ethylene-diamino-tetraacetic acid; GABA, g-aminobutyric acid; HPLC, high performance liquid chromatography; MALDI-MS, matrix-assisted laser desorption/ionization mass spectrometry. 